ks. Wojciech Medwid

Kraków

\title{
Papieska elekcja i posługa w dokumentach soboru we Florencji
}

Pontyfikat papieża Eugeniusza IV (1431-1447) był naznaczony siedemnastym soborem Kościoła katolickiego, który powszechnie określa się jako sobór florencki, mimo że jego obrady odbywały się w czterech różnych miejscach. Pierwszym była Bazylea, choć zgodnie z postanowieniami soboru w Konstancji (1414-1418 $)^{1}$ kolejne zgromadzenie ojców miało być zwołane pięć lat po zakończeniu poprzedniego soboru. Zdecydowano wówczas, że zgromadzenie odbędzie się w mieście Pawia w 1423 roku, jednakże przybyło niewielu delegatów i obrady przeniesiono do Sieny. Ta decyzja nie polepszyła sytuacji i sobór zakończono bezowocnie. Należy zaznaczyć, że przeniesienie obrad oficjalnie spowodowane było wybuchem epidemii, a tak naprawdę przyczyną okazała się afera w Peniscola. W maju 1423 roku umarł antypapież Benedykt XIII (Piotr de Luna), który dnia 26 lipca 1417 roku został usunięty z urzędu papieskiego. W czerwcu 1423 roku dokonano wyboru antypapieża Klemensa viı. Król Aragonii poparł ów wybór i wykorzystał tę sytuację przeciwko papieżowi Marcinowi v (1417-1431), wskazując na nową schizmę. Mając za podstawę dokumenty soboru w Konstancji - trzeba było suspendować obediencje jednego i drugiego papieża. Oni z kolei mieli obowiązek oddać się do dyspozycji soboru. Z tego względu Marcin v wskazał wspomnianą Bazyleę oraz rok 1431 na miejsce soboru powszechnego, ale jego otwarcia dokonał Eugeniusz IV, gdyż Marcin v umarł pół roku wcześniej. Zgromadzenie ojców miało priorytety

1 Por. Sobór w Konstancji, sesja 39, I, 2, [w:] Dokumenty soborów powszechnych, t. 3, układ i oprac. A. Baron, H. Pietras, Kraków 2003, s. 211. 
w postaci reformy Kościoła, usunięcia herezji husytyzmu oraz zaprowadzenie pokoju między władcami chrześcijańskimi².

Jednakże większość obradujących w Bazylei żyła ideami teorii koncyliarystycznej, które nie były tożsame z poglądami ówczesnego biskupa Rzymu. Ojcowie zajęli się między innymi takimi kwestiami, jak: zwoływanie soborów, wybór i obowiązki papieża, sprawy związane z kardynałami, biskupami i synodami oraz unia z Grekami. Trzeba podkreślić, że priorytetem soboru stała się jedność Kościoła i z tego względu wysłano zaproszenie do rozmów przedstawicielom Kościołów wschodnich. Aby ułatwić spotkanie z tymi ostatnimi, papież przeniósł zgromadzenie do Ferrary, zaś ci, którzy pozostali w Bazylei, obradowali jeszcze do 1443 roku. W Ferrarze prowadzono rozmowy w latach 1438-1439, a następnie przeniesiono sobór do Florencji (1439-1442) i tam ogłoszono unię z Grekami (uzgodniono sprawę słynnego Filioque, prymatu papieskiego, czyśćca i konsekracji chleba), z Ormianami (kwestia siedmiu sakramentów) i z Koptami (temat dogmatu trynitarnego i chrystologicznego, kanonu Pisma Świętego, usprawiedliwienia, dobra stworzenia i kary piekła). Po czym obrady kontynuowano w Rzymie (1443-1445), gdzie podpisano unię z Syryjczykami (potwierdzono prawdy dogmatyczne z soboru chalcedońskiego i konstantynopolitańskiego III) oraz Chaldejczykami i maronitami z Cypru (podkreślono prymat papieża, Filioque, chrystologię i sprawę sakramentów) i zakończono sobór ${ }^{3}$. Celem artykułu jest odpowiedź na pytanie, w jaki sposób sobór florencki określił wybór papieża, jego kompetencje i znaczenie w przewodnictwie Kościołowi i na ile funkcja biskupa Rzymu miała wpływ na przezwyciężenie idei koncyliarystycznych. Najwięcej istotnych treści w interesującym nas temacie zostało zawartych w dokumentach obrad w Bazylei.

\section{Bazylejskie idee soborowe a papieski prymat}

Na początku warto wskazać, że od czasu soboru w Konstancji (1414-1418) istniał problem zależności i podziału władzy między papieżem a soborem: czy papież stoi nad soborem czy sobór nad papieżem? Idąc dalej, czy następca św. Piotra ma prawo rozwiązać zgromadzenie ojców czy też przenieść je w inne dogodne miejsce? Soborowi zwolennicy koncyliaryzmu powoływali

2 Por. Sobór w Bazylei, sesja 1, I, 1-4. II, 1-3, [w:] Dokumenty soborów powszechnych, dz. cyt., s. 279-281; J. Gill, The Council of Florence, Cambridge 2011, s. 4-8.

3 Por. B. Kumor, Historia Kościoła, t. 4, Lublin 2001, s. 72-74; N. Hamennan, The Council of Florence. The religious event that shaped the era of discovery, „Fidelio” 1 (1992) no. 2, 23-26. 
się na dekret Haec sancta ${ }^{4}$ z Konstancji, który określił nadrzędność soboru nad rzymskim biskupem. Kiedy papież Eugeniusz IV chciał przenieść sobór z Ferrary do Bolonii, większość kardynałów, na czele z przewodniczącym soboru kardynałem Julianem Cesarinim, nie zgodziła się na taką propozycję. Dla papieża priorytetowe stały się rozmowy na temat unii z Grekami. Dnia 12 listopada 1431 roku Eugeniusz IV opuścił zgromadzenie w Bazylei, przenosząc obrady do wspomnianej wyżej Bolonii. W zaistniałych okolicznościach, miesiąc później, ojcowie z Bazylei upomnieli papieża, domagając się, aby odwołał dekret o rozwiązaniu soboru i powrócił wraz z kardynałami do Bazylei. Po czym przełożeni soboru oskarżyli papieża o nieuzasadniony upór, który będzie miał - ich zdaniem - negatywne skutki dla jedności Kościoła. Po upływie półtora roku, we wrześniu 1433 roku, przedłużono termin przyłączenia się papieża do soboru bazylejskiego na okres 90 dni ${ }^{5}$. Można w tej sytuacji mówić o żądaniu od papieża stwierdzenia nieważności dokumentu, ogłaszającego rozwiązanie obrad i jednocześnie o zagrożeniu procesem i zdjęciem z urzędu papieskiego, jeśli nie zostaną spełnione soborowe postulaty. Przymuszony papież ustąpił i odwołał bulle rozwiązujące sobór, co było niewątpliwie potwierdzeniem zwycięstwa idei soborowej. W lutym 1434 roku Eugeniusz IV przystąpił do soboru. Dołączono wówczas do akt soborowych jego bullę Dudum sacrum ${ }^{6}$, która miała przeciwdziałać ruchowi soborowemu. W relacji papież-sobór nie okazała się ona czymś trwałym. Uzależnienie biskupa Rzymu od soboru dokonało się na ten czas przez zniesienie annat ${ }^{7}$, opłat paliuszowych i taks kancelaryjnych. W ten sposób zgromadzenie soborowe musiało utrzymać finansowo papieża. Trzeba podkreślić, że sobór, będąc w konflikcie z papieżem, nie przyczynił się do osiągnięcia jedności, o którą tak mocno walczył. Przeniesienie obrad do Ferrary, a później do Florencji spowodowało ostateczny rozłam na linii papież-sobór. Mniejsza część uczestników zgromadzenia w Bazylei stanęła po stronie „papieskiej”, w tym Mikołaj z Kuzy (1401-1464), uważany za jedną z podwalin idei koncyliarystycznych. Natomiast pozostali ojcowie zerwali z papieżem. Warto zaznaczyć, że król Zygmunt Luksemburski (1368-1437)

4 Por. Sobór w Konstancji, sesja 5: dekret Haec sancta, [w:] Dokumenty soborów powszechnych, dz. cyt., s. 47-51.

5 Por. J. D. Mansi, Sacrorum Conciliorum Nova et Amplissima Collectio, vol. 29, Paris 1901, kol. 45-52, 64-74.

6 Por. Eugenius Iv, Dudum sacrum, [w:] J. D. Mansi, Sacrorum Conciliorum..., dz. cyt., kol. 78-79; N. Valois, La crise religieuse du xve siècle, Paris 1909, s. 302-310.

7 Kwestia annat była poważną sprawą na soborze w Konstancji i w Bazylei. Por. J. Dudziak, Dziesięcina papieska w Polsce średniowiecznej, Lublin 1974, s. 20-21. 
nakłaniał Eugeniusza Iv do odstępstwa w tej kwestii, gdyż zależało mu na porozumieniu $\mathrm{z}$ husytami, którzy stanowili poważne zagrożenie polityczne, a z którymi sobór nawiązał dialog ${ }^{8}$.

Nadrzędność soboru nad papieżem wyraziła się w przedstawionych przez ojców zadaniach, które miał spełnić biskup rzymski. Przede wszystkim nie mógł on przeszkadzać w jakikolwiek sposób soborowym obradom oraz miał wspomagać wszelkimi środkami zgromadzenie ojców. W czasie nieobecności papieża w Bazylei chciano, aby przybył on na obrady, choć w swoim imieniu mógł wysłać inne osoby, udzielając im pełnej władzy odnośnie do wszystkich spraw podejmowanych na soborze. W przeciwnym wypadku to właśnie ojcowie soborowi mieli zająć się rozwiązaniem problemów Kościoła, obradując zgodnie z zasadami prawa Bożego9. Można przy tej okazji sądzić, że ojcowie byli przygotowani na przewodniczenie obradom i podejmowanie decyzji bez udziału papieża, tym bardziej że idee koncyliaryzmu były bliskie uczestnikom w Bazylei.

Po opuszczeniu bazylejskiego soboru przez Eugeniusza IV ojcowie orzekli, że nikt, nawet papież, po pierwsze, nie mógł odważyć się tworzyć i organizować innego zgromadzenia, nazywając je soborem generalnym, nawet pod pretekstem obietnicy czy też złożonej przysięgi. Nie mógł również w jakikolwiek sposób brać udziału ani odwoływać się do tego zgromadzenia. Po drugie, bez zgody soboru nie miał możliwości (mocą swojej władzy papieskiej) rozwiązać soboru bazylejskiego i przenieść go w inne miejsce. Jeśli postąpiły inaczej i działał tym samym na szkodę soboru przez ograniczenie, przeniesienie i kary kościelne, to sobór miał unieważnić, znieść i anulować tego typu postanowienia. Aby zmienić miejsce obrad przyszłego soboru, musiała być zgoda dwóch trzecich kardynałów oraz wskazane określone przypadki, na mocy dekretu z soboru w Konstancji ${ }^{10}$. Jeśli papież zaniedbałby podjęcie takiej decyzji, to podejmie ją kolegium kardynałów, przy zgodzie co najmniej dwóch trzecich. Po trzecie, nie miał także możliwości przedłużenia czasu odroczenia soboru. Po czwarte, jakikolwiek zakaz, nawet papieski, nie mógł stanowić przeszkody

8 Por. K. Schatz, Sobory powszechne, przekł. J. Zakrzewski, Kraków 2001, s. 150; H. ZeppLaRouche, Nicolaus of Cusa and the Council of Florence, „Fidelio” 1 (1991) no. 2, s. 17-22; C. Eubel, Hierarchia catholica medii aevi, sive Summorum pontificum, vol. 2, Monasterii 1913, s. 78.

9 Por. Sobór w Bazylei, sesja 3, 3-5, [w:] Dokumenty soborów powszechnych, dz. cyt., s. 285-287.

10 Por. Sobór w Konstancji, sesja 39, I, 4, [w:] Dokumenty soborów powszechnych, dz. cyt., s. 211-213; M. Creighton, The Council of Basel, London 2011, s. 57-58. 
dla żadnej z osób w swobodnym przybyciu na sobór ${ }^{11}$. Ojcowie bazylejscy swoimi decyzjami chcieli ukazać, że prawowicie zgromadzony może być tylko sobór, którego obrady trwają obecnie, a propozycje papieża nie mogły w żaden sposób naruszyć integralności i ciągłości zgromadzenia. Aby przenieść sobór, konieczne było uzyskanie zgody soboru, to jest zdecydowanej większości kardynałów.

\section{Procedury elekcji papieskiej}

Podczas obrad w Bazylei zajęto się sprawą elekcji biskupa Rzymu. Ojcowie podkreślili prawomocność trwającego soboru oraz to, że reprezentuje on Kościół powszechny. Zamiarem zgromadzenia było wytępienie herezji, co miało skutkować uspokojeniem chrześcijańskiego ludu i odnowieniem obyczajów. Z tego względu zostali wezwani kardynałowie świętego Kościoła rzymskiego, którzy cieszyli się autorytetem i odznaczali się mądrością oraz rozeznaniem w analizowanych sprawach. Podkreślono, że w przypadku wakansu na Stolicy Apostolskiej, który pojawiłby się w trakcie trwania obrad soborowych, wybór nowego biskupa Rzymu miał się odbyć tam, gdzie na ten czas obradowaliby ojcowie. Nie było możliwości, aby elekcja papieska odbyła się w innym miejscu. Trzeba zaznaczyć, że zgromadzeni w Bazylei, co było do przewidzenia, zabezpieczyli się na wypadek, gdyby działano wbrew powyższym ustaleniom soboru. Przeciwne decyzje, podejmowane nawet w mocy autorytetu papieskiego, jak również przez inną władzę czy osoby oraz potwierdzone przysięgą, miały być zniesione przez sobór i nieważne, a mocą prawa nie miały żadnej wagi i znaczenia. Ponadto osoby, które postępowałyby przeciwnie do ustalonych zasad, miały zostać na zawsze pozbawione czynnego i biernego prawa wyboru na papieża, jak również wszystkich innych godności. Takie postępowanie ipso facto miało spowodować jawną infamię (utrata czci i dobrego imienia) i wyrok ekskomuniki. Ojcowie poszli jeszcze dalej i przewidując tego typu wybór, stwierdzili, że ten, kto dążyłby do tej elekcji oraz jej uczestnicy i osoby współpracujące, popadną w taki sam sposób w wyżej wymienione kary $^{12}$. Według mnie rygorystyczne orzecznictwo miało na celu ścisłą kontrolę nad prawidłową papieską elekcją. Chciano przez to uniknąć sytuacji z okresu

${ }_{11}$ Por. Sobór w Bazylei, sesja 8, 2, sesja 11, II-IV. V, 5, [w:] Dokumenty soborów powszechnych, dz. cyt., s. 303, 307-309; M. Randall, The Gargantuan polity, London 2008, s. 19-21.

12 Por. Sobór w Bazylei, sesja 4, II, 1-4, [w:] Dokumenty soborów powszechnych, dz. cyt., s. 297-299; O. La Rocca, Il conclave. Le procedure, i protagonisti, la storia, le curiosita, Milano 2005, s. 38-40. 
schizmy papieskiej (1378-1417), kiedy to poszczególne obediencje wybierały spośród siebie „swoich” następców św. Piotra i w rezultacie doprowadzono do stanu, w którym było równocześnie trzech papieży i każdy z nich uważał się za prawowicie wybranego.

Uzupełniając kwestie związane z wakatem na Stolicy Apostolskiej podczas obrad soborowych, ojcowie podali w wątpliwość okres dziesięciu dni, który został wyznaczony do wejścia na konklawe dla kardynałów, co wcześniej określiła konstytucja soboru lyońskiego (1274). W momencie śmierci papieża w mieście, w którym rezydował, będący tam kardynałowie mieli czekać na nieobecnych przez dziesięć dni. Po tym czasie, bez względu na ich przybycie bądź nie, pozostali mieli się zebrać w pałacu, w którym mieszkał papież $\dot{1}^{13}$. Ów czas trwał od momentu stwierdzenia przez dany sobór wakansu, co wydawało się bardzo sztywne. Okres dziesięciu dni był zbyt krótki dla wielu kardynałów, przez wzgląd na ich odległość od miejsca obrad. Miało to służyć jedności Kościoła, pokojowi wśród chrześcijańskiego ludu i podkreśleniu wiary katolickiej. Można przy tej okazji mówić o soborowej rozwadze i właściwej dojrzałości przez wydłużenie owego czasu. Gdyby w trakcie soboru pojawiła się sytuacja wakansu na Stolicy Apostolskiej, trzeba przystąpić do elekcji papieskiej przed upływem sześćdziesięciu dni od momentu stwierdzenia tego faktu. Postanowiono także, iż papież nie będzie miał możliwości rozporządzania dochodami z beneficjów kardynałów ${ }^{14}$.

W celu łatwiejszego zachowania soborowych przepisów odnoszących się do zwoływania soborów i wyboru papieża, postanowiono, że elektorzy, którzy będą wybierać nowego biskupa Rzymu, przed wejściem na konklawe złożą przysięgę Bogu i Kościołowi. Obietnica ta dotyczyła roli i funkcji nowego papieża, który będzie musiał zachować wspomniane wyżej dekrety, ustalenia i rozporządzenia oraz będzie się starał o ich rzeczywiste i skuteczne wypełnienie. Poza tym przyszły papież musiał również złożyć przysięgę realizacji postanowień dekretu z soboru w Konstancji, odnośnie do oświadczenia, które powinien złożyć nowo wybrany papież $\dot{1}^{15}$. Mając do dyspozycji soborowe orzecz-

${ }_{13}$ Por. Sobór Lyoński II, konst. II/2, 2, [w:] Dokumenty soborów powszechnych, t. 2, dz. cyt., s. 417.

${ }_{14}$ Por. Sobór w Bazylei, sesja 7, [w:] Dokumenty soborów powszechnych, t. 3, dz. cyt., s. 301; A. Nowicki, Prymat papieski na Soborze Florenckim i w Unii Brzeskiej, „Colloquium Salutis” 20 (1990), s. 135-139.

${ }_{15}$ Por. Sobór w Konstancji, sesja 39, III, [w:] Dokumenty soborów powszechnych, dz. cyt., s. 219-221. 
nictwo, ojcowie chcieli, aby nowy biskup Rzymu realizował we właściwy sposób swoją posługę. Owo wyznanie miał ponowić podczas pierwszego publicznego konsystorza. Jeśliby natomiast popełnił jakiekolwiek jawne przestępstwo, gorszące Kościół, to miał się oddać pod osąd soboru. Instancją kontrolującą posługę papieską $\mathrm{w}$ dalszym ciągu był więc sobór. Papież wraz z kardynałami do wyznania musiał dołączyć listy, które później miały być rozesłane po świecie. Dokument soborowy określił, że podczas konklawe elektorzy powinni wysłuchać mszy o Duchu Świętym, prosząc przy tym pokornie o wsparcie $\mathrm{w}$ wyborze godnego pasterza. W podejmowaniu decyzji podczas elekcji papieskiej znaczącym czynnikiem stała się duchowość elektorów ${ }^{16}$.

$\mathrm{Na} 23$ sesji soborowej w Bazylei, 26 marca 1436 roku, ojcowie wraz z papieżem Eugeniuszem IV zajęli się kwestią wyboru papieża. Na początku zostało podkreślone, że dobry Pasterz (J 10, 11. 14) to zbawienie dla ludu. Z tego względu słuszną sprawą jest, aby sobór zatroszczył się o odpowiednią osobę na biskupa Rzymu, gdyż jawił się on jako pierwszy i najwyższy pasterz owczarni Pańskiej i dlatego ma być to człowiek dbający o zbawienie wszystkich dusz, jak również o pożytek całego chrześcijańskiego świata. W tym wszystkim musiał godnie wypełniać swoje obowiązki. Rolą papieża - jako przewodnika dusz - było zabieganie o zbawienie wiernych. Ojcowie postanowili odnowić konstytucje świętych soborów wraz z orzeczeniami papieży, dotyczące papieskiej elekcji. Trzeba zaznaczyć, że zapewne chodziło o orzecznictwo określające wybór papieża z synodu rzymskiego (1059) wraz z bullą Mikołaja II (1058-1061) In nomine Domini ${ }^{17}$; z Decretum Gratiani ${ }^{18}$; z soboru laterańskiego III (1179) ${ }^{19}$; z soboru lyońskiego II $(1274)^{20}$ oraz z soboru w Konstancji ${ }^{21}$. Jeśli zdarzy się sytuacja wakatu Stolicy Apostolskiej, to kardynałowie, obecni na miejscu elekcji nowego biskupa Rzymu na dziesiąty dzień od momentu wakatu, mają się zebrać na konklawe w kaplicy bądź w innym właściwym do tego miejscu ${ }^{22}$.

${ }_{16}$ Por. Sobór w Bazylei, sesja 11, vi; sesja 12, 5, [w:] Dokumenty soborów powszechnych, dz. cyt., s. 311, 315; A. Melloni, Konklawe. Historia wyboru papieża, przekł. K. Kozak, Poznań 2005, s. 65-68.

17 Por. J. D. Mansi, Sacrorum Conciliorum..., dz. cyt., kol. 903-904.

18 Por. Decretum Gratiani. Corpus Iuris Canonici, vol. 1, instruxit A. Friedberg, Leipzig 1879, dist. XXIII, cap. 1, s. 77-99.

19 Por. Sobór Laterański III, kan. 1, [w:] Dokumenty soborów powszechnych, t. 2, dz. cyt., s. 169.

${ }^{20}$ Por. Sobór Lyoński II, konst. II/2, [w:] Dokumenty soborów powszechnych, dz. cyt., s. 415-423.

${ }^{21}$ Por. Sobór w Konstancji, sesja 12, III; sesja 14, II; sesja 4O, III; sesja 41, [w:] Dokumenty soborów powszechnych, t. 3, dz. cyt., s. 107, 113-115, 225-237.

${ }_{22}$ Por. Sobór w Bazylei, sesja 23, I, 1, [w:] Dokumenty soborów powszechnych, dz. cyt., s. 373-375. 
Podano przy tej okazji procedury przebiegu konklawe. Elektorzy, po dwóch, w procesji mieli wejść za krzyżem, śpiewając hymn Przybądź Duchu Święty $y^{23}$. Sobór zgodził się na udział w wyborze papieża osób spoza kolegium kardynalskiego. Elektorzy mogli mieć przy sobie co najwyżej dwie niezbędne osoby ze służby do odprawiania nabożeństw. $Z$ kolei papieskiemu szambelanowi ${ }^{24}$ wyznaczono konkretne zadania odnośnie do czuwania nad przebiegiem konklawe. Po pierwsze, miał on strzec, aby nikt niepożądany nie dostał się na konklawe, a po drugie, gdy już kardynałowie wejdą na konklawe i zostaną zamknięte drzwi, musiał dokładnie sprawdzić cele poszczególnych elektorów. Gdyby znalazł w nich artykuły spożywcze lub potrawy - musiał je usunąć. Mógł zostawić tylko leki dla chorych i słabych. Zadaniem szambelana była kontrola codziennych posiłków dostarczanych kardynałom, aby w sposób umiarkowany wzmacniali swoje siły witalne. Następnego zaś dnia kardynałowie, po wysłuchaniu mszy o Duchu Świętym, mieli przyjąć świętą Eucharystię $e^{25}$. Ojcowie za wszelką cenę dążyli do tego, aby przebieg konklawe odbył się bez żadnych komplikacji i aby zostały zachowane wszelkie wymogi. Kontrola koniecznego wyżywienia miała zapewne służyć szybszemu decydowaniu się $\mathrm{w}$ wyborze, a brak aprobaty na inne zbędne rzeczy - zapobieganiu niepotrzebnemu rozpraszaniu się. Sobór miał na celu, aby kardynałowie podczas konklawe zajmowali się tylko wyborem nowego papieża.

Kolejnym elementem w procedurze elekcji papieskiej było postanowienie, że przed rozpoczęciem obliczania głosów każdy elektor musiał złożyć przysięgę na Ewangelię. Zawierała ona następujące obietnice dotyczące wyboru papieża. Po pierwsze, miała to być osoba użyteczna dla Kościoła powszechnego w sprawach duchowych i świeckich oraz zasługująca na tak wielką godność. Po raz kolejny podkreślono, że zadaniem papieża była przede wszystkim troska o zbawienie wiernych. Po drugie, nie można było zagłosować na osobę, która starała się o swój wybór drogą obietnic, wręczania dóbr doczesnych, modlitw zanoszonych osobiście bądź przy udziale innych osób. Po trzecie, okazanie obediencji kandydata wybranego na papieża było możliwe dopiero po złożeniu

${ }^{23}$ Hymn ten powszechnie jest przypisywany mnichowi benedyktyńskiemu Rabanusowi Maurusowi (780-856).

${ }^{24}$ Początkowo był to dworzanin papieski, który miał dostęp do prywatnych pomieszczeń papieża i pełnił służbę przy nim. Dziś to funkcja kamerlinga, będącego zarządcą Stolicy Apostolskiej w czasie wakatu, czyli po śmierci papieża bądź po jego abdykacji, jak w sytuacji Benedykta Xvi.

${ }_{25}$ Por. Sobór w Bazylei, sesja 7; sesja 23, I, 2, [w:] Dokumenty soborów powszechnych, dz. cyt., s. 301, 375; M. Creighton, The Council of Basel, dz. cyt., s. 62-65. 
przez niego przysięgi, w formie określonej przez sobór bazylejski. Kandydat na papieża miał prezentować sobą czyste intencje swojego kandydowania i wyboru, a przez to wzbudzić zaufanie u reszty kolegium. Następnym etapem elekcji papieskiej było oddanie przez każdego z kardynałów kartki z nie więcej niż trzema imionami kandydatów. Zaznaczono, iż w ciągu jednego dnia powinno się odbyć tylko jedno głosowanie, bezpośrednio po mszy. Natomiast gdyby większość głosów nie wskazała jednej osoby, należało spalić kartki. Wskazano w procedurach, iż przed szóstym głosowaniem nie będzie możliwości dokonania wyboru żadnego kandydata. W takiej sytuacji kardynałowie mieli się zastanowić i rozważyć, co przyniesie im wybór takiego papieża: czy będzie owocny, czy też stanie się zagrożeniem dla chrześcijańskiego ludu ${ }^{26}$. Z tego względu, iż papież jawił się jako wikariusz Jezusa Chrystusa i przewodnik owczarni, jego wybór mógł ściągnąć na kardynałów łaskę lub gniew Boży. Ojcowie chcieli w ten sposób podkreślić odpowiedzialność kardynałów, dokonujących wyboru najważniejszej osoby dla Kościoła, który powinien być „bez skazy i bez zarzutu” (1 Tm 6, 14).

W szczegółowej procedurze elekcji papieskiej sobór zdecydował się, aby nowo wybrany biskup Rzymu wyraził zgodę na dokonany wybór jego osoby. Jeżeli papież będzie przebywał w kurii, zgoda zostanie wyrażona wobec kardynałów. Jeśli nie, to wobec jednego z kardynałów albo posiadającego odpowiednie upoważnienie. Po stwierdzeniu faktu wyboru elekt miał obowiązek złożyć zgodę w ciągu jednego dnia od momentu wiadomości o powyższym zobowiązaniu. Warto podkreślić, że we wszystkich procedurach, nie tylko związanych z wyborem papieża, ojcowie podali sposób postępowania w przypadku działania odmiennego niż orzecznictwo soborowe. Jeśli papież nie wyraziłby zgody, jego wybór uzna się za nieważny, zaś kardynałowie przystąpią do wyboru kogoś innego. Natomiast przy wyrażeniu zgody przez nowo wybranego papieża kardynałowie złożą odpowiednią obediencję jako najwyższemu pasterzowi ${ }^{27}$.

Odpowiedzialne i jednoznaczne podejście ojców soborowych do wyboru papieża wyraziło się w tekście zgody, którą przyszły biskup Rzymu musiał złożyć przed kardynałami. Zawarto w niej następujące przesłanie. Wyznanie

${ }_{26}$ Por. Sobór w Bazylei, sesja 23, I, 3-4, [w:] Dokumenty soborów powszechnych, dz. cyt., s. 375-377; J. Gill, The Council of Florence, dz. cyt., s. 59-62.

${ }_{27}$ Por. Sobór w Bazylei, sesja 23, II, [w:] Dokumenty soborów powszechnych, dz. cyt., s. 377; C. Bellitto, 101 questions \& answers on popes and the papacy, New York 2008, s. 45-46. 
i obietnica papieska dokonują się przed Bogiem i św. Piotrem, Księciem Apostołów ${ }^{28}$, a papież przyjmuje w rządzeniu Kościół, będący pod Bożym zwierzchnictwem. Biskup Rzymu ma zachować wiarę katolicką, zgodną z Tradycją Apostolską, soborami powszechnymi i świętymi ojcami. Wymieniono osiem soborów starożytnych, począwszy od nicejskiego I (325), przez konstantynopolitański I (381), efeski (431), chalcedoński (451), konstantynopolitański II (553), aż do konstantynopolitańskiego III (68o-681), oraz kolejne sobory, czyli konstantynopolitański IV (869-870), cztery laterańskie (1123, 1139, 1179, 1215), dwa lyońskie (1245, 1274), w Vienne (1311-1312), w Konstancji (1414-1418) i obecny bazylejski. Zaznaczono, iż treść wiary, zawarta w powyższych dokumentach, ma być w sposób niewzruszony zachowana przez papieża (por. Mt 5,18 ) oraz broniona i głoszona przez niego aż do utraty życia. Odnośnie do rytów i sakramentów przekazanych Kościołowi biskup Rzymu ma obowiązek przestrzegać ich $^{29}$. Ojcowie jasno określili, że papież przez piastowanie najwyższej godności w Kościele jest depozytariuszem dziedzictwa przekazanego przez orzecznictwo soborowe i ma go strzec oraz być mu wierny. Trzeba zaznaczyć, iż powyższa część „formuły zgody” została przyjęta wcześniej na soborze w Konstancji.

Obietnica papieża zawierała także wierną troskę o zachowanie wiary katolickiej oraz wytępienie herezji i błędów, jak również odnowę obyczajów i pokój wśród chrześcijańskiego ludu. Przysięga dotyczyła też odprawiania soborów generalnych i zatwierdzania wyborów, zgodnych z dekretem obecnego soboru. Papież - w wizji ojców - był moralnym autorytetem i stróżem doktryny wiary oraz porządku eklezjalnego. Papieskie wyznanie musiało być osobiście podpisane przez papieża i złożone z czystym sercem na ołtarzu przed Bogiem, a następnie powtórzone na pierwszym publicznym konsystorzu ${ }^{30}$.

${ }_{28}$ Sformułowanie „Piotr, książę apostołów” pojawia się we wcześniejszym piśmiennictwie: Faustynus Luciferianus, De Trinitate, [w:] Corpus Christianorum. Series Latinorum, vol. 69, Turnhout 1999, s. 341; J. Kasjan, De incarnatione Domini contra Nestorium, [w:] Corpus Scriptorum Ecclesiasticorum Latinorum, vol. 17, Wien 2004, s. 74; Euzebiusz z Cezarei, Historia kościelna, przekł. A. Caba, Kraków 2013, s. 91 oraz w dokumentach IV soboru w Konstantynopolu, kan. 21, 2, [w:] Dokumenty soborów powszechnych, t. 2, dz. cyt., s. 94-95 i soboru w Konstancji, sesja 15, Iv, 13, [w:] Dokumenty soborów powszechnych, t. 3, dz. cyt., s. 139.

29 Por. Sobór w Bazylei, sesja 23, IIIa, 1, [w:] Dokumenty soborów powszechnych, dz. cyt., s. 377-379; Sobór w Konstancji, sesja 39, III, 2, [w:] Dokumenty soborów powszechnych, dz. cyt., S. 219-221.

30 Por. Sobór w Bazylei, sesja 23, IIIa, 2, [w:] Dokumenty soborów powszechnych, dz. cyt., s. 379; J. Gill, The Council of Florence, dz. cyt., s. 67. 
Ojcowie soborowi zdecydowali, że każdego roku w rocznicę wyboru albo koronacji papieskiej w czasie mszy św. pierwszy z kardynałów ma publicznie odczytać wobec biskupa Rzymu oświadczenie, w którym zwróci uwagę na dotrzymanie obietnicy, złożonej przez niego w dniu jego wyboru, oraz zachęci go do dalszej troski dla chwały Bożej, własnego zbawienia i pożytku Kościoła powszechnego. Sugerowało to nieustanne przypominanie, jak odpowiedzialną i ważną funkcję dzierży następca św. Piotra. Papież musiał mieć w świadomości, że jest zastępcą Jezusa na ziemi, który oddał życie za swoje owce. Z tego względu miał się liczyć z tym, iż Pan może zażądać od niego podobnego poświęcenia życia. Powinien mieć również na uwadze osobę św. Piotra, którego jest następcą, oraz wcześniejszych papieży. Ci ostatni - podkreślili ojcowie - głosili wiarę, troszczyli się o zbawienie wiernych i dobro Kościoła. Poza tym nie wahali się oddać życia za powierzone sobie owce, ponieważ byli naśladowcami Mistrza z Nazaretu. Sobór chciał ukazać prawdę, iż papież powinien być świadomy swojej funkcji i gotowy do największych poświęceń w służbie Bogu i wiernym, których miał w swojej pieczy. Podano także przestrogę dla przyszłego następcy św. Piotra, aby nie gromadził skarbów na ziemi dla siebie ani dla innych osób, ale gromadził sobie skarby w niebie, gdyż tam ani mól, ani rdza nie niszczą, a złodzieje nie włamują się i nie kradną (por. Mt 6, 19-20). W pełnieniu swojej posługi nie powinien mieć względu na osoby, pochodzenie, ojczyznę czy naród, ponieważ jego trosce i opiece zostały powierzone jednakowo wszystkie dzieci Boże. Przy rozdzielaniu godności i beneficjów papież nie mógł brać pod uwagę osób i dóbr doczesnych, gdyż musiał zważać wyłącznie na wzgląd Boży. Sobór chciał zaakcentować duchowe bogactwo i troskę o wieczność papieża oraz wolność od jakichkolwiek wpływów, które utrudniałyby mu w przyszłości pełnienie misji oraz stawiałyby go w negatywnym świetle. W swojej posłudze biskup rzymski powinien przestrzegać dyscypliny kościelnej oraz bronić, wspomagać i wspierać ubogich i nieszczęśliwych, kierując się ojcowską miłością ${ }^{31}$.

\section{Prerogatywy i obowiązki biskupa Rzymu}

Jednym z wyznaczników posługi biskupa Rzymu, określonym przez sobór bazylejski, było postanowienie, że papież w trakcie trwania soboru nie może ustanawiać kardynałów ani podawać do publicznej wiadomości ich imion.

${ }_{31}$ Por. Sobór w Bazylei, sesja 23, IIIa, 3, [w:] Dokumenty soborów powszechnych, dz. cyt., s. 379-381; M. Randall, The Gargantuan polity, dz. cyt., s. 32-35; W. Klimiuk, Podatek kościelny. Idea, konstrukcja i recepcja $w$ prawie polskim, Warszawa 2015, s. 21. 
Ojcowie swoją decyzję motywowali tym, że zwiększona liczba kardynałów mogła zaszkodzić Kościołowi i być dla niego ciężarem. Podparto się w tej kwestii rozsądkiem, powodami prawnymi i sprawdzoną wiedzą, choć nie podano konkretnych wyjaśnień. Być może chodziło o to, aby do prac soborowych i ewentualnego wyboru papieża nie włączano dodatkowych osób, niezorientowanych w temacie. Papież Eugeniusz Iv był oddalony od miejsca soboru w Bazylei, gdyż w Bolonii zajmował się rokowaniami w sprawie unii z Grekami. Z tego względu nie mógł nikogo przybrać sobie za kardynała. W tym przypadku bez znaczenia były, z jednej strony, godność, stan, stopień czy ranga kardynała, a z drugiej, pretekst bądź przyczyna wyboru i zarówno sekretne, jak i publiczne obwieszczenie o tym fakcie. Gdyby papież zdecydował się i ustanowił ich, to ów wybór stałby się bezwartościowy i pozbawiony mocy. Z kolei uznający się w taki sposób za kardynałów ipso facto zaciągną na siebie karę ekskomuniki ${ }^{32}$. Powyższymi decyzjami ojcowie podkreślili rangę instytucji soboru, który nie tylko mógł obradować bez udziału papieża, ale także miał możliwość rozporządzać orzecznictwem dyscyplinarnym i wyznaczać zakres zadań ludzi Kościoła.

Papież, który dla wiernych był zwierciadłem i wzorem wszelkiej świętości i czystości, nie mógł się domagać żadnych korzyści doczesnych przy zatwierdzaniu wyników wyborów biskupów i prałatów. Nie powinien także występować wbrew dekretom o wyborach i zatwierdzeniu biskupów i prałatów, chyba że byłaby szczególna ku temu przyczyna. W przeciwnym wypadku, przy braku poprawy i zgorszeniu Kościoła przez papieża, sprawę miał rozpatrzyć przyszły sobór ${ }^{33}$. Zapewne na tym tle dochodziło do wielu nadużyć, które w negatywny sposób oddziaływały na wizerunek Kościoła, a przede wszystkim papieża. Chciano wykluczyć wszelkie zależności personalne w tym względzie po to, aby postawa biskupa Rzymu była bez zastrzeżeń, gdyż wymagała tego pełniona przez niego funkcja.

Ojcowie bazylejscy określili także obowiązki papieża. Miał on każdego roku, w rocznicę swojego wyboru, wraz z kardynałami wnikliwie przemyśleć, w jaki sposób ma wypełniać złożone przed Bogiem obietnice. Po raz kolejny sobór wskazał na papieską świadomość wyboru i zleconej mu misji prowadzenia Kościoła. Podano, jakie sfery życia Kościoła powinna obejmować owa refleksja. Po pierwsze, gdzie religia chrześcijańska jest uciskana przez Turków,

${ }^{32}$ Por. Sobór w Bazylei, sesja 4, III, [w:] Dokumenty soborów powszechnych, dz. cyt., s. 299; A. Nowicki, Prymat papieski na Soborze Florenckim i $w$ Unii Brzeskiej, dz. cyt., s. 140-141.

33 Por. Sobór w Bazylei, sesja 12, 14, [w:] Dokumenty soborów powszechnych, dz. cyt., s. 319. 
Saracenów, Tatarów i pozostałych niewiernych. Po drugie, w jakich miejscach rozwija się herezja, schizma czy przesądy. Po trzecie, gdzie upadają obyczaje, zachowywanie przykazań Bożych i zasady prawego życia, odnoszące się do spraw kościelnych i świeckich. Po czwarte, gdzie jest zagrożona wolność Kościoła i gdzie trwa nienawiść, wojna albo jej zagrożenie między królami, książętami i ludźmi. W tych wszystkich sprawach - zdaniem soboru - papież miał przyjść z pomocą, używając wszelkich odpowiednich do tego środków i postępując jak pobożny ojciec. Ojcowie podkreślili misję pasterską biskupa Rzymu oraz obowiązek jak najlepszego rozeznania życia w Kościele. Z jednej strony, to szeroko pojęta kontrola, a z drugiej, ojcowska troska. Do zadań biskupa Rzymu należało również zajęcie się najbliższymi sprawami oraz odnowa kurii rzymskiej. Papież miał się wzorowo zatroszczyć o wszystko, co konieczne, aby pozostałe Kościoły podległe rzymskiemu, realizowały czystość obyczajów i konieczne reformy, oraz zadbać o naprawę tego, co jest konieczne i pilne. Sobór swoim orzecznictwem ukazał rangę papieża i Kościoła rzymskiego oraz sprzeniewierzenie się następcy św. Piotra, które powodowało osłabienie wizerunku prymatu papieskiego ${ }^{34}$.

Obradujący na soborze wskazali, że dom papieski i kuria rzymska, ze względu na swoją doniosłość, muszą być czyste jak lustro. Papież z kolei miał w sposób gruntowny dokonać naprawy i usunąć wszystko, co mogłoby być splamione symonią albo konkubinatem, czyli to, co było w stanie obrazić Boga albo zgorszyć wiernych. Związane z tym było odnowienie kultu Bożego w rzymskich kościołach. Poza tym - jeśli idzie o urzędników papieskich - to papież miał dopilnować, aby godziwie pełnili swoje obowiązki i nie uciskali nikogo, jak również nie wymuszali niczego przez pogróżki i niegodziwe postępowanie. Miał wydać w tym względzie zakaz noszenia strojów i barw zakazanych kanonami soborowymi ${ }^{35}$. Biskup Rzymu swoją nauczycielską troską powinien otoczyć bezpośrednio poddane mu duchowieństwo rzymskie w kwestii kościelnej uczciwości. Można wnioskować, że intencją soboru był fakt, aby nie tylko papież, ale także jego najbliższe otoczenie, stanowiące Kościół rzymski, było bez zastrzeżeń i stanowiło wzór dla innych. Dlatego najbliżsi współpra-

${ }_{34}$ Por. Sobór w Bazylei, sesja 23, IIIb, 4-5, [w:] Dokumenty soborów powszechnych, dz. cyt., s. 381-383; K. Ziebart, Nicolaus Cusanus on faith and the intellect, Leiden 2013, s. 149-150.

${ }_{35}$ Zapewne ojcowie soborowi mieli na uwadze w tym temacie następujące orzecznictwo: Sobór Konstantynopolitański Iv, kan. 27, [w:] Dokumenty soborów powszechnych, t. 2, dz. cyt., s. 103-105; Sobór Laterański IV, konst. 16, [w:] Dokumenty soborów powszechnych, dz. cyt., s. 255 i Sobór w Vienne, dekr. 9, [w:] Dokumenty soborów powszechnych, dz. cyt., s. 545. 
cownicy papieża mieli odznaczać się takimi cnotami, jak: pokora, czystość umysłu, prostota serca i skromność obyczajów ${ }^{36}$.

Pod względem przewodnictwa następca św. Piotra miał troszczyć się o pouczanie i prowadzenie oraz kierowanie na drogę zbawienia rzymskiego ludu. Kardynałowie zaś z polecenia papieskiego mieli otoczyć troską swoje kościoły tytularne i parafie, a rzymscy wikariusze - duchowieństwo i lud. Zadaniem papieża w tej kwestii miała być $\mathrm{z}$ jednej strony częsta kontrola spełniania ich obowiązków, aby zarządzano sprawiedliwie i w pokoju, a z drugiej - wspieranie z ojcowską miłością. W zarządzaniu Kościołem papież miał sprawować pieczę nad dobrami doczesnymi Kościoła rzymskiego i wraz z kardynałami rozważyć sposób dobrego i zbawiennego dysponowania nimi. Należy podkreślić, że odpowiedzialność papieska odnosiła się do spraw duchowych i świeckich, a co za tym idzie - musiał on zachować wszystkich w jednomyślności w obronie Kościoła, usuwając wszelkie zarzewie niezgody ${ }^{37}$.

Papież w swojej posłudze - według wizji soboru - sprawował także funkcję nadzorcy. W zarządzaniu prowincjami i głównymi miastami papieżowi mieli służyć pomocą kardynałowie i inni dostojnicy, odznaczający się nieskazitelną opinią i brakiem dążenia do zdobywania korzyści majątkowych. Obowiązkiem biskupa Rzymu w tej materii miało być rozpatrywanie spraw, co do których nie znaleziono stosownego rozwiązania, oraz dokładne badanie sprawozdań zarządców prowincji. Zaznaczono, iż nie może on być pobłażliwy w sytuacji nakładania na barki poddanych zbytnich ciężarów i niesprawiedliwych podatków. Jeśli papież dostrzeże jakąś niegodziwość, której się dopuszczono, to wymierzy odpowiednią karę, będącą przestrogą dla innych zarządców. Sądzić można, iż powinnością papieża miało być dbanie o pełne zachowywanie postanowień i zwyczajów, sprzyjających pożytecznemu rządzeniu prowincjami i ziemiami, jak i rozeznanie sytuacji na poszczególnych terenach. Poza tym miał on co dwa lata kontrolować prowincje i stosować środki zaradcze, w celu wynagrodzenia ewentualnych szkód i dla publicznego dobra. Papież nie mógł w tym względzie nakładać nowych świadczeń na ziemiach Kościoła rzymskiego ani też ogłaszać w przyszłości i korzystać z ogólnej rezerwacji kościołów metropolitarnych, katedralnych, kolegiackich i klasztornych oraz godności pochodzących z wyboru. Ponadto niestosownym byłoby występować

${ }^{36}$ Por. Sobór w Bazylei, sesja 23, IIIb, 6, [w:] Dokumenty soborów powszechnych, t. 3, dz. cyt., s. 383; J. Gill, The Council of Florence, dz. cyt., s. 78-80.

37 Por. Sobór w Bazylei, sesja 23, IIIb, 7-9, [w:] Dokumenty soborów powszechnych, dz. cyt., s. 383-385; M. Creighton, The Council of Basel, dz. cyt., s. 91-92. 
przeciw dekretowi odnośnie do rezerwacji kościołów i wybieranych godności, chyba że miałby ku temu poważne, rozumne i oczywiste przyczyny. W przypadku wyboru mogącego zagrażać pokojowi w Kościele, państwu czy dobru publicznemu, po rozpatrzeniu sprawy i zasięgnięciu opinii od kardynałów, należy odrzucić wybór ${ }^{38}$.

$\mathrm{W}$ dokumencie soborowym poruszono temat relacji papieża do krewnych, mając zapewne w pamięci złe doświadczenia w tej kwestii i aby uniknąć zgorszenia. Postanowiono w tym względzie, że biskup Rzymu powinien bardziej kierować się osądem sumienia niż więzami pokrewieństwa i dlatego nie może sam tego uczynić ani zezwolić, żeby jego krewni bądź powinowaci do trzeciego stopnia włącznie byli mianowani książętami, margrabiami, wasalami, dziedzicznymi dzierżawcami, wikariuszami, gubernatorami, urzędnikami i kasztelanami. Nie mogli także posiadać jurysdykcji ani władzy nad podanymi powyżej osobami. Dotyczyło to miejsc sprawowania ich funkcji w prowincjach, miastach, zamkach, twierdzach i na terenie całego Kościoła rzymskiego. Jeśli papież mianowałby kogoś z krewnych, to następny papież dokonałby ich odwołania i unieważnienia tej decyzji. Było to oczywiście wyjściem naprzeciw powszechnej w średniowieczu praktyce wynoszenia przez papieży swoich bliskich do różnych godności i stanowisk, co określano mianem nepotyzmu. Z papieżem było związane miejsce sprawowania posługi. Wraz z kardynałami zdaniem ojców z Bazylei - miał on troszczyć się o wszystkie ziemie Kościoła rzymskiego, gdyż spoczywają tam święte szczątki apostołów Piotra i Pawła oraz wielu innych męczenników i świętych Pańskich. Była to zarówno siedziba cesarstwa, jak i miejsce, gdzie przybywali z pobożności czciciele Chrystusa. Wymagało to od biskupa Rzymu, aby Wieczne Miasto było rządzone w pokoju, sprawnie i sprawiedliwie ${ }^{39}$.

Warto podkreślić, że przy formułowaniu postawy i obowiązków papieża, odpowiedzialnego za cały Kościół i wszystkie jego sfery, wskazano na dyspozycyjność biskupa Rzymu, uważającego się za sługę sług Bożych, co miało się potwierdzać w czynach. Do papieża miał być łatwy dostęp, gdyż był on ojcem wszystkich. $Z$ tego względu powinien mieć wyznaczony jeden dzień $w$ tygodniu na publiczne audiencje, przyjmując wiernych, szczególnie ubogich

${ }_{38}$ Por. Sobór w Bazylei, sesja 23, IIIb, 10-12. V, 1-2, [w:] Dokumenty soborów powszechnych, dz. cyt., s. 385. 401; A. Nowicki, Prymat papieski na Soborze Florenckim i w Unii Brzeskiej, dz. cyt., s. $144-147$.

39 Por. Sobór w Bazylei, sesja 23, IIIb, 14. 17-18, [w:] Dokumenty soborów powszechnych, dz. cyt., s. 385-389; M. Randall, The Gargantuan polity, dz. cyt., s. 38-40. 
i pokrzywdzonych, oraz służyć radą i pomocą. Gdyby jednak zdarzyło się jego fizyczne niedomaganie, to miał zlecić rozpatrywanie sprawy jednemu z kardynałów albo innym znaczącym mężom. Wraz z dyspozycyjnością papieską związane były publiczne wystąpienia i dlatego w niedziele i święta miał publicznie odprawić mszę św., a potem udzielić audiencji zainteresowanym. Z kolei publiczne konsystorze powinny odbywać się raz w tygodniu albo przynajmniej dwa razy w miesiącu, a ich celem miało być zapoznanie papieża ze sprawami kościołów katedralnych, klasztorów, książąt i uniwersytetów, a także z innymi kwestiami wielkiej wagi. Biskup Rzymu, przez wzgląd na swoją godność, uchodził za najwyższego pasterza oraz najznaczniejszego ojca i pasterza wszystkich. Jeśli chodzi o najbliższych współpracowników, to kierując społecznością chrześcijańską, papież był najściślej zjednoczony z kardynałami świętego Kościoła rzymskiego, którzy mieli się zająć poważniejszymi i trudniejszymi publicznymi problemami. Ponadto, z własnej inicjatywy miał on obowiązek zlecić wykrywanie chorób swoich synów i zadbać o zastosowanie zbawiennych lekarstw. Jeśli kardynałowie stwierdziliby jakiekolwiek zaniedbanie, zlekceważenie papieskie albo uczynienie przez niego czegoś wbrew swojemu stanowi, to - w przypadku braku poprawy - wezwą go do powstrzymania się od zaniedbań. Papieżowi w tej sytuacji miało grozić oddanie jego sprawy najbliższemu soborowi. Jeśli natomiast któryś z kardynałów dopuściłby się lekkomyślnych i nagannych czynów, to biskup rzymski miał pouczyć go z ojcowską miłością i ewangeliczną nauką ${ }^{40}$.

\section{Papieski prymat}

Papież Eugeniusz IV przeniósł 18 września 1437 roku sobór z Bezylei do Ferrary. Uczestnicy obrad z Bazylei, 31 lipca 1437 roku wydali upomnienie i wezwanie do ustąpienia papieża, postanowiono również, iż w trakcie soboru papież nie może mianować nowych kardynałów. Następnie ogłoszono upór w trwaniu w błędzie papieża i odwołano bullę papieską z 18 września 1437 roku o przeniesieniu soboru z Bazylei do Ferrary. Z kolei 24 stycznia 1438 roku ojcowie suspendowali Eugeniusza IV i wskazali wyższość soboru nad papieżem i nielegalność przeniesienia obrad do Ferrary. Natomiast 25 czerwca 1439 roku złożono z urzędu Eugeniusza Iv. Dnia 26 lutego 1440 roku ogłoszono przyjęcie papiestwa przez księcia Amadeusza, który obrał imię Feliks v, zaś 24 lipca 1440

${ }^{40}$ Por. Sobór w Bazylei, sesja 23, IIIb, 19-21. IV, 13, [w:] Dokumenty soborów powszechnych, dz. cyt., s. 389, 395; K. Ziebart, Nicolaus Cusanus on faith and the intellect, dz. cyt., s. 151-155. 
roku w Bazylei uroczyście koronowano nowego papieża, a Eugeniusza IV potępiono i uznano za heretyka. Jednakże we wrześniu 1440 roku Karol viı, król Francji, zobowiązał wszystkich poddanych do uznania Eugeniusza Iv. Tak samo postanowili książę Bretanii i król Kastylii. Feliks v w 1442 roku przeniósł się do Lozanny. Z kolei Mikołaj v bullą z 1449 roku uznał sesje odbyte w Bazylei do wyjazdu Eugeniusza Iv ${ }^{41}$.

Trzeba zaznaczyć, że na początku obrad w Ferrarze papież Eugeniusz IV i zgromadzeni ojcowie określili kary kościelne przeciwko uczestnikom synodu w Bazylei, o którym powiedziano, że jest zbiegowiskiem, zgorszeniem i bezbożnością. Zaciągnęli oni wszyscy karę ekskomuniki, pozbawienie godności i stwierdzenie niezdolności do przyjmowania beneficjów i urzędów. To wszystko, co postanowił ów synod od dnia przeniesienia obrad do Ferrary, stało się nieważne i bez żadnej mocy wiążącej. Natomiast bullą Decet oecumenici concilii z 10 stycznia 1439 roku papież przeniósł sobór z Ferrary do Florencji. W bulli unii z Grekami z 6 lipca 1439 roku we Florencji ojcowie wskazali dwie istotne kwestie związane z prymatem papieża i Stolicą Apostolską. Po pierwsze, Stolica Apostolska i biskup rzymski dzierżyli prymat nad całym światem, zaś papieżowi przysługiwały takie tytuły, jak: następca św. Piotra, Księcia Apostołów; prawdziwy zastępca Chrystusa; głowa Kościoła; ojciec i nauczyciel wszystkich chrześcijan. Ponadto, posiadał on władzę pasterzowania, rządzenia i kierowania Kościołem powszechnym, co było zgodne z orzecznictwem soborów ekumenicznych i świętych kanonów ${ }^{42}$. Po drugie, podano porządek hierarchiczny stolic patriarchalnych. Po biskupie rzymskim drugi był patriarcha Konstantynopola, trzeci - Aleksandrii, czwarty - Antiochii, a piąty - Jerozolimy ${ }^{43}$. Jasno podkreślono najwyższą władzę nauczycielską i kierowniczą

${ }^{41}$ Por. J. Stieber, Pope Eugenius IV, the Council of Basel and the Secular and Ecclesiastical Authorities in the Empire, Leiden 1978, s. 48-55; J. D. Mansi, Sacrorum Conciliorum Nova et Amplissima Collectio, dz. cyt., kol. 137-180.

${ }_{42}$ Por. Sobór we Florencji, sesja 6: Unia z Grekami, 17, [w:] Dokumenty soborów powszechnych, dz. cyt., s. 475. W tym temacie można wskazać na następujące orzecznictwo: Sobór Konstantynopolitański I, kan. 3, [w:] Dokumenty soborów powszechnych, t. 1, dz. cyt., s. 73; Sobór Chalcedoński, kan. 28, [w:] Dokumenty soborów powszechnych, dz. cyt., s. 251; Sobór Konstantynopolitański Iv, kan. 21, 1, [w:] Dokumenty soborów powszechnych, t. 2, dz. cyt., s. 93, 95; Sobór Laterański Iv, konst. 5, [w:] Dokumenty soborów powszechnych, dz. cyt., s. 237; Sobór w Konstancji, sesja 40, III, 4, [w:] Dokumenty soborów powszechnych, t. 3, dz. cyt., s. 235.

43 Por. Sobór we Florencji, sesja 6: Unia z Grekami, 18, [w:] Dokumenty soborów powszechnych, dz. cyt., s. 477. Kolejność stolic wcześniej podaje Sobór Konstantynopolitański Iv, kan. 21, 1, [w:] Dokumenty soborów powszechnych, t. 2, dz. cyt., s. 93, 95; Sobór Laterański Iv, konst. 5, 1, [w:] 
biskupa Rzymu oraz uznano rzymską stolicę jako pierwszą w ramach pięciu stolic patriarchalnych. Nie określono jednak, w jaki sposób miały się do siebie powyższe kwestie i na ile się ograniczały. Bez wątpienia dla papieża pierwsze stwierdzenie było stwierdzeniem dogmatycznym, a drugie - czcigodnym zwyczajem. Dla Greków Rzym był głową w kontekście wspomnianych pięciu stolic. Unia była na pewno niemałym osiągnięciem na tamte czasy, biorąc pod uwagę współczesny ekumeniczny punkt widzenia ${ }^{44}$. Z kolei na sesji dziewiątej (23 czerwca 1440) w monitorium soboru florenckiego przeciw antypapieżowi Feliksowi v ojcowie zaznaczyli, iż papieżowi, w osobie św. Piotra, została przekazana przez Jezusa władza kluczy wiązania i rozwiązywania (por. Mt 16, 19) ${ }^{45}$.

\section{Podsumowanie}

Należy wskazać, że uczestnicy obrad w Bazylei zdefiniowali w sposób dogmatyczny koncyliaryzm jako powszechną i bezwarunkową wyższość soboru nad papieżem. Przekonani byli o następujących kwestiach, po pierwsze - sobór powszechny stał nad biskupem Rzymu; po drugie, papież nie miał możliwości rozwiązać soboru, odroczyć go ani przenieść w inne miejsce; po trzecie, kto sprzeciwiał się soborowym ustaleniom, ten stawał się heretykiem. Eugeniusz IV nie przyjął tych prawd, więc naturalną konsekwencją było, iż został złożony z urzędu papieskiego jako heretyk. Papież Eugeniusz IV w 1444 roku w bulii Etsi non debitum ogłosił dekret Haec sancta $\mathrm{z}$ Konstancji za nieważny, gdyż w tym czasie sobór w Konstancji, składający się tylko z obediencji antypapieża Jana XxIII (1410-1415), nie był jeszcze ekumeniczny. Zwycięstwo papiestwa było okupione większymi stratami niż osiągniętymi korzyściami. Ówczesne zaś możliwości podróżowania, które dla organizowania regularnych soborów były za dużym wyzwaniem, wpłynęły na osłabienie dominacji idei koncyliarystycznych ${ }^{46}$.

Ojcowie soborowi z jednej strony stwierdzili przewodnią rolę papieża nad całym Kościołem powszechnym, uznali go za prawdziwego zastępcę Chrystusa i następcę świętego Piotra oraz podkreślili pierwsze miejsce Rzymu wśród stolic patriarchalnych, co bez wątpienia było ukazaniem wartości prymatu

Dokumenty soborów powszechnych, dz. cyt., s. 237 oraz wspomina Sobór Laterański IV, konst. 30, 4, [w:] Dokumenty soborów powszechnych, dz. cyt., s. 269.

${ }_{44}$ Por. J. Gill, The Council of Florence, dz. cyt., s. 178; K. Schatz, Sobory powszechne, dz. cyt., S. 152.

${ }^{45}$ Por. Sobór we Florencji, sesja 9, 5, [w:] Dokumenty soborów powszechnych, t. 3, dz. cyt., s. 545.

46 Por. J. Stieber, Pope Eugenius IV..., dz. cyt., s. 61-64. 
papieskiego. Z drugiej jednak strony, mając zapewne na uwadze troskę o papieża oraz wcześniejsze negatywne w skutkach urzędowanie jednocześnie trzech papieży, określili konkretne zadania i priorytety biskupa Rzymu, które powinien - w myśl soboru - rzetelnie i odpowiedzialnie wypełnić, zaznaczając tym samym, iż funkcje pasterskie i kierownicze miał realizować przy uwzględnieniu postanowień soborów ekumenicznych i świętych kanonów. Podano ponadto dokładne procedury dotyczące elekcji nowego biskupa rzymskiego i związaną z tą funkcją odpowiedzialnością. Z powyższego przesłania ojców z Bazylei wynika, iż papież jawił się jako wykonawca orzecznictwa soborowego, a przekonanie koncyliarystów o soborowej władzy nadrzędnej wyrażało się w dobru dla Kościoła, którym było posłuszeństwo papieskie. Koncyliaryzm oddziaływał na naukę Jana Husa, gallikanizm i jansenizm. Idee koncyliarne ostatecznie zostały przezwyciężone na soborze Watykańskim I (1870), kiedy zdefiniowano papieską nieomylność.

\section{ABSTRAKT}

\section{Papieska elekcja i posługa w dokumentach soboru we Florencji}

Artykuł ma na celu odpowiedzieć na pytanie, w jaki sposób sobór florencki zdefiniował wybór papieża, jego kompetencje i znaczenie przewodnictwa Kościołowi oraz jak papieska funkcja wpłynęła na przezwyciężenie koncyliaryzmu. Sobór pokazał przewodnią rolę papieża nad Kościołem powszechnym i określił konkretne zadania i priorytety biskupa Rzymu oraz procedury jego wyboru. W przypadku wakatu w Stolicy Apostolskiej, który powstałby w trakcie obrad soborowych, wybór nowego biskupa Rzymu miał mieć miejsce tam, gdzie obradują ojcowie. Przed wejściem na konklawe elektorzy mieli złożyć przysięgę Bogu i Kościołowi. Papież jest pierwszym i najwyższym pasterzem owczarni Chrystusa i dlatego musi być osobą zatroskaną o zbawienie wszystkich dusz i o pożytek dla całego świata chrześcijańskiego. Biskup Rzymu ma zdecydowanie wyznawać i zachować wiarę katolicką, według tradycji apostolskiej, soborów powszechnych i świętych ojców. Papież musi być świadomy swojej funkcji i gotowy do największych poświęceń w służbie Bogu i wiernym. Ma także dbać o prowadzenie i kierowanie na drogę zbawienia duchowieństwa i ludu rzymskiego oraz musi naprawiać i usuwać wszystko, co może być skażone symonią lub konkubinatem. Papież nie może kierować się więzami pokrewieństwa, ma być dostępny dla wiernych.

\section{SŁOWA KLUCZOWE}

sobór we Florencji, koncyliaryzm, wybór papieża, obowiązki biskupa Rzymu, prymat papieski, Eugeniusz IV 


\section{Abstract}

\section{Papal election and ministry in the documents of the council in Florence}

This article aims to answer the question how the Florentine council defined the election of the Pope, his competence and importance in the conductivity of the Church and how his function influenced on overcoming conciliarism. The council showed the leading role of the pope over the universal Church and identified specific tasks and priorities of the Bishop of Rome, and the procedures the election of the Pope. In case of vacancy of the Holy See, which arise in the course of the meeting the council, election of a new bishop of Rome is to take place where at that time shall debate fathers. Before entering the conclave electors take the oath to God and the Church. The Pope is the first and the highest shepherd of sheepfold of Christ and therefore he has to be a person caring for the salvation of all souls and the advantage of the whole Christian world. The Bishop of Rome has strongly profess and preserve the Catholic faith, according to the Apostolic Tradition, the councils common and holy fathers. The Pope has to be aware of his function and ready for the greatest sacrifices in the service of God and the faithful, and he has to take care of conducting and directing the path of salvation, the clergy and the Roman people, and he has to repair and remove anything that could be tainted with simony or concubine. He can't follow the ties of kinship and shall be available for the faithful.

\section{KEYWORDS}

council in Florence, conciliarism, election of the pope, duties of the Bishop of Rome, papal primacy, Eugene IV

\section{BiBLIOGRAFIA}

Bellitto C., 101 questions \& answers on popes and the papacy, New York 2008. Creighton M., The Council of Basel, London 2011.

Decretum Gratiani. Corpus Iuris Canonici, vol. 1, instruxit A. Friedberg, Leipzig 1879.

Dudziak J., Dziesięcina papieska w Polsce średniowiecznej, Lublin 1974.

Eubel C., Hierarchia catholica medii aevi, sive Summorum pontificum, vol. 2, Monasterii 1913.

Gill J., The Council of Florence, Cambridge 2011.

Hamennan N., The Council of Florence. The religious event that shaped the era of discovery, „Fidelio” 1 (1992) no. 2, s. 23-36.

Klimiuk W., Podatek kościelny. Idea, konstrukcja i recepcja w prawie polskim, Warszawa 2015. 
Kumor B., Historia Kościoła, t. 4, Lublin 2001.

La Rocca O., Il conclave. Le procedure, i protagonisti, la storia, le curiosita, Milano 2005. Mansi J. D., Sacrorum Conciliorum Nova et Amplissima Collectio, vol. 29, Paris 1901. Melloni A., Das Konklave. Die Papstwahl in Geschichte und Gegenwart, Wien 2002. Nowicki A., Prymat papieski na Soborze Florenckim i w Unii Brzeskiej, „Colloquium Salutis" 20 (1990), S. 135-152.

Pope Eugenius Iv, Dudum sacrum, [w:] J. D. Mansi, Sacrorum Conciliorum Nova et Amplissima Collectio, vol. 29, Paris 1901, kol. 78-79.

Randall M., The Gargantuan polity, London 2008.

Sobór w Bazylei, [w:] Dokumenty soborów powszechnych, t. 3, układ i oprac. A. Baron, H. Pietras, Kraków 2003, s. 279-427.

Sobór we Florencji, sesja 6: Unia z Grekami, [w:] Dokumenty soborów powszechnych, t. 3, układ i oprac. A. Baron, H. Pietras, Kraków 2003, s. 459-477.

Sobór w Konstancji, [w:] Dokumenty soborów powszechnych, t. 3, układ i oprac. A. Baron, H. Pietras, Kraków 2003, s. 31-269.

Stieber J., Pope Eugenius IV, the Council of Basel and the secular and ecclesiastical authorities in the Empire, Leiden 1978.

Schatz K., Sobory powszechne, przekł. J. Zakrzewski, Kraków 2001.

Valois N., La crise religieuse du Xve siècle, Paris 1909.

Ziebart K., Nicolaus Cusanus on faith and the intellect, Leiden 2013.

Zepp-LaRouche H., Nicolaus of Cusa and the Council of Florence, „Fidelio” 1 (1991), no. 2, s. 17-22. 
